\title{
THE GOVERNANCE OF MIGRATION THROUGH THE MEDITERRANEAN: A TRANSNATIONAL PERSPECTIVE
}

\author{
Anna Elia ${ }^{1 *}$, Valentina Fedele ${ }^{1 *}$ \\ ${ }^{1}$ Author affiliation: Department of Social and Political Sciences, University of Calabria Arcavacata di \\ Rende (C.S.), Italy. \\ * Corresponding author: Anna Elia - anna.elia@unical.it; Valentina Fedele - valentina.fedele16@gmail.com
}

Received: 08.03.2021; Accepted: 10.04.2021; Published: 17.05.2021

Doi: https://doi.org/10.46473/WCSAJ27240606/17-05-2021-0004

Category: Research paper

\begin{abstract}
The paper aims to verify the reproduction of 'modern coloniality' through externalising the European borders in Tunisia, Morocco and Algeria, focusing particularly on its discursive and practical articulations. Crossing Critical Border Studies' approaches and an analytical view on the policies and agreements supporting the externalisation politics, we have tried to trace the evolution of the external dimension of E.U. migration policy from the perspective of both the countries of the Francophone Maghreb and of the member states of the European Union. The results show that beyond the rhetoric of the global approach to externalisation of borders adopted by the EU, Maghrebian states have implemented forms of resistance and accomplishment to make their global political agenda prevail over E.U. attempts to manage the Mediterranean governance migration.
\end{abstract}

Keywords: Borders, externalisation, Maghreb, modern coloniality, migration policy.

\section{Introduction}

Analysis on the process of the externalisation of European borders toward a third country has generally focused more on the issue of sovereignty and borders (Casas-Cortés et al., 2010; Mountz 2011) when compared to economic issues, but also highlight humanitarian constraints (Andersson 2014; Gammeltoft-Hansen and Sørensen, 2013). A Critical Border Studies perspective conceives of borders as relational and socially constructed through discourses, practices, norms, material and immaterial configurations and sees them as defined by different governmental and non-governmental actors (Parker and Vaughn-Williams, 2016; Mezzadra and Neilson, 2013; Gross-Wyrtzen, 2019). From this point of view, some colonial epistemologies "on" and "around" the border can be identified, the definition for which represents a form of modern coloniality, conceived as a way of knowledge-making, which assumes, in this specific case, Eurocentrism as the basis of the organisation of global relationships, and the definitions of freedom, mobility, and humanity (Quijano, 2007; Mignolo, 2011; Afailal and Fernandez, 2018). Such an ethnic, racial classification of the world's population defines the ground for a model of power operating at every material and subjective level, for different aims and declinations.

This article reflects on the reproduction of modern coloniality, focusing on the externalisation 
of European borders toward the Francophone Maghreb area - Tunisia, Morocco, Algeria - and particularly on its discursive and practical articulations. The main argument is that this process determines socio-political and cultural norms and narratives of inclusion and exclusion, to which both European and North African countries contribute, albeit from different perspectives. An attempt to format North African migration politics and policies on European models raises forms of both resistance and accomplishment. The externalisation of E.U. borders determines forms of prevarication in terms of interference in national sovereignty, creating, in parallel, discursive and narrative categories, which transform national and supranational geographies, following not territorial, but racial classifications, dividing between (European and North African) migrants and citizens and between European countries and countries to which control is outsourced (Grosfoguel, 2011). The reflections proposed to revolve around two main categories: the transit country and a safe country.

\section{The EU borders' externalisation toward the Francophone Maghreb}

In June 2018, the closure of the Italian ports to migrants and an NGO's rescue boat declared by the then Minister of the Interior, Matteo Salvini, has been followed by the E.U. proposal to implement disembarkment platforms for migrants ${ }^{1}$. These platforms were presented during an informal meeting on migration between E.U. heads of state and government. They were to be implemented in two ways. The first is people rescued in E.U. territorial waters, or from a ship flying the flag of a member state, who would have landed on platforms on European soil and there would be planning for the relocation of potential asylum seekers, set within a future agreement between member states. The second is for people rescued in the territorial waters of a third state or international waters, regardless of the ship's flag, who would be disembarked on platforms built-in third states, compensated by economic aid, where the United Nations High Commissioner for Refugees (UNHRC) would manage asylum seekers, while the International Organization for Migration (IOM) would take care of the repatriation of the other migrants. The African states gathered on 2 July 2018 at the African Union summit rejected the plan, formalising their opposition in a joint document in February 2019, that considered the Brussels' plan as the establishment on African soil of detention centres, without consulting the African Union and violating both the sovereignty of African countries and the internationally recognised right of asylum ${ }^{2}$. This opposition is symbolic of the failing of an E.U. common strategy for the externalisation of borders, on-going from the very creation of the Schengen area in Europe. As early as 1990, an attempt was made to establish, at least, a regional dialogue strategy with the countries of North Africa, as exemplified by the $5+5$ dialogue - involving Spain, France, Italy, Malta, Portugal, Algeria, Libya, Morocco, Mauritania and Tunisia - that represented the prelude to the 1995 Barcelona process, which aimed at defining a framework and some cooperation projects among Mediterranean countries on political, securitarian, economic,

\footnotetext{
${ }^{1}$ cfr. Barricelli F. (2018), Il calo degli sbarchi in Italia e i porti chiusi voluti da Salvini, available at https://www.agi.it/cronaca/migranti_italia_salvini-4781759/news/2018-12-31/

${ }^{2}$ cfr. EU-ALS Summit Overshadowed by AU Document Thwarting EU Plans for 'Disembarkation Platforms', 1st March 2019, Available at https:/www.ecre.org/eu-las-summit-overshadowed-by-au-document-thwarting-euplans-for-disembarkation-platforms/; Africa-EU Migration, Mobility and Employment Partnership, available at https:/ec.europa.eu/home-affairs/what-we-do/networks/european_migration_network/glossary_search/africa-eumigration-mobility-and en\#: :text=Definition(s),to\%20better\%20manage $\% 20$ migration $\% 20$ flows. See also Bisiaux S.-A. (2020), « La Tunisie, terre d'accueil... des politiques européennes », Plein Droit, 2, 125; Merlo A. M. (2018), UE su migranti e Brexit: cadono le maschere, available at https://ilmanifesto.it/ue-su-migranti-ebrexit-cadono-le-machere/
} 
financial, cultural, social and human issues ${ }^{3}$. The following Barcelona Declaration was signed at the Euro-Mediterranean Conference of the 27-28/11/95 by the E.U. and twelve Mediterranean countries ${ }^{4}$ to strengthen cooperation in various fields, particularly migration, and involved readmission agreements for the expulsion of irregular migrants. This common regional strategy has a milestone in 2005, after the dramatic events of September of that year in Ceuta ${ }^{5}$, where five migrants died, and 28 were injured while trying to cross the border barrier with Spain. After this, the European Council adopted a proposal for a new 'Strategy for Africa' to strengthen cooperation on migration with African countries ${ }^{6}$. This proposal was followed two years later, in 2007, in Lisbon with the launching of the EU-Africa Partnership for Migration, Mobility and Employment to improve coherence and efficacy. It was later revised in 2011 to include a chapter on mobility, involving, among others, Morocco (2013) and Tunisia $(2014)^{7}$.

Despite the commitment to foster a regular dialogue on mobility, migration and asylum, marked by the EU-Algeria partnership of $2017^{8}$, Algeria has not joined the partnership as part of a national non-cooperation strategy concerning border externalisation. According to Zardo and Loschi (2020), this may depend on many reasons, among which is the substantial economic independence of Algeria - allowing the country to make its national interests on migration prevail over the E.U. ones, even if sometimes they converge, in a country where full sovereignty and non-interference is a constitutional dogma. Thus, the Association Agreements, which became effective in $2005^{9}$, formally include Algeria in the framework of European mobility without giving rise to effective implementation of undermining national policies in the field. Nevertheless, it has not prevented the country from proceeding with bilateral agreements as a major part of Algerian foreign policy and, simultaneously, of the policy of the externalisation of European borders. Between 1997 and 2006, the Algerian government concluded bilateral readmission agreements with Germany (1999), Italy (2000), Spain (2004), Switzerland and the United Kingdom (2006), as well as a protocol to combat irregular migration and human trafficking with France (2008). Internationally, Algeria has also ratified the Palermo Protocols against Smuggling and Human Trafficking $(2004)^{10}$ as the major UN convention on the subject, and it was the first Arab country to join the International Organization of Migration in 2009.

Algeria is, in this sense, an exception among Francophone Maghreb countries. In Tunisia and Morocco, the process of E.U. borders' externalisation in exchange for economic aid has been more rapid and pervasive (Bisaux 2020). Tunisia, which over time has become a pivotal country for the E.U. borders' externalisation strategy, especially after the Libyan crisis, has, for example, signed a series of agreements with Italy since 1998 concerning the readmission of Tunisian migrants and of migrants who have passed through Tunisia, and the creation of detention

\footnotetext{
3 cfr. The Barcelona Process or Euro-Mediterranean Partnership, available at

https://www.barcelona.com/barcelona_news/the_barcelona_process_or_euro_mediterranean_partnership

4Algeria, Cyprus, Egypt, Israel, Jordan, Lebanon, Malte, Morocco, Syria, Tunisia, Turkey, and Palestine, cfr. Barcelona declaration adopted at the Euro-Mediterranean

Conference - 27-28/11/95, available at http://ec.europa.eu/research/iscp/pdf/policy/barcelona_declaration.pdf

5Le Monde, L'assaut d'immigrants sur l'enclave espagnole de Ceuta a fait cinq morts, available at https://www.lemonde.fr/international/article/2005/09/29/1-assaut-d-

immigrants-sur-1-enclave-espagnole-de-ceuta-a-fait-cinq-morts_694052_3210.html

6cfr. A NEW EU-AFRICA STRATEGY - A PARTNERSHIP FOR SUSTAINABLE AND INCLUSIVE DEVELOPMENT / BEFORE 2020-04, available at,

https://ec.europa.eu/commission/presscorner/\#fn1

7cfr. Africa-EU Partnership on Migration, Mobility and Employment (MME), available at https://www.iom.int/es/africa-eu-partnership-migration-mobility-and-employment-

mme

8cfr. DOCUMENT DE TRAVAIL CONJOINT DES SERVICES Rapport sur l'état des relations UE-Algérie dans le cadre de la PEV rénovée Mars 2017, available at

https://eeas.europa.eu/sites/eeas/files/rapport_sur_letat_des_relations_ue-algerie_dans_le_cadre_de_la_pev_renovee.pdf

9cfr. Association agreement, https://www.eumonitor.eu/9353000/1/j9vvik7m1c3gyxp/vh7dosdm4dzj

10cfr. Palermo Protocol, available at https://ec.europa.eu/home-affairs/what-we-do/networks/european_migration_network/glossary_search/palermo-protocol_en
} 
centres in the country financed by Italy, in exchange for quotas of regular Tunisian workers admitted to Italy. In particular, on 13 December 2003, an agreement on police cooperation between the two states was signed. In exchange for immigration quotas for Tunisian workers, Italy committed to training and strengthening the technical capabilities of the Tunisian police forces for the control of sea borders. On 27 January 2009, another agreement allowed the acceleration of the identification and expulsion of immigrants from Tunisia, revised in 2011 after the fall of the Ben Ali regime and the increase in the number of migrants arriving in Italy through Tunisia ${ }^{11}$.

The relevance of Tunisia as a transit country has also determined its involvement within the wider European strategy: after the Barcelona process in 1995, the E.U. signed a first association agreement with Tunisia, which culminated in 2004 with the country's inclusion in the European Neighbourhood Policy (ENP) aiming to complete and strengthen the Barcelona process according to three priority areas of cooperation: economic development, security, and migration and mobility ${ }^{12}$. In this context, the E.U. has been implementing "Mobility Partnerships" (M.P.) since 2007, which generally consist of a visa facilitation agreement for signatory countries in exchange for readmission agreements, dividing migrants between those who are desirable and those who are not ${ }^{13}$. From this point of view, a privileged partnership was signed on 19 November $2012^{14}$, implemented through a 2013-2017 action plan that also fostered the signing of a deep and comprehensive free-trade agreement (ALECA) in $2015^{15}$. The MPC also provides for the development of specific Tunisian asylum legislation through collaboration with the UNHCR, a privileged player in outsourcing asylum. On 3 March 2014, Tunisia signed a joint declaration with the E.U. implementing an MPC that planned to develop a series of practices, mainly concerning the identification of people to be readmitted, both Tunisians and migrants in transit. These initiatives are accompanied by E.U. financial support through the MPF - Mobility Partnership Facility - of 2016, and the Trust Funds for Africa (FFU) of 2015, established at the Valletta summit, which between 2011 and 2018brought Tunisia to benefit from 2.5 million euros from the MPF and, after 2016, from 57 million from the FFU linked for $65 \%$ to the management of migratory flows and borders, for $15 \%$ for institutional support and capacity building in the governance of migration policies, $10 \%$ for the promotion of the rights of migrants in Tunisia, $7 \%$ for the fight against human trafficking and 3\% for the socio-economic integration of immigrants and refugees ${ }^{16}$.

Morocco has also been one of the first participants in the E.U. borders externalisation programmes due to its position on the Strait of Gibraltar and its continuity to the two Spanish enclaves of Ceuta and Melilla. In exchange for strengthening the national borders, the E.U. and especially Spain have heavily invested in Moroccan infrastructure, offering different financial incentives in the form of aid, special trade status, and facilitation of remittances for expatriates. In terms of operational actions, among the various interventions aimed at improving the capacity of Morocco to manage workers' migration to Europe, the E.U. has been supporting Morocco since 2013 through the implementation of its National Strategy on Migration and

\footnotetext{
11 cfr., Storie migranti, Cronologia degli accordi Italia - Tunisia, available at http://www.storiemigranti.org/spip.php?article1004

12 cfr. European Neighbourhood Policy, available at https://ec.europa.eu/neighbourhood-enlargement/neighbourhood/european-neighbourhood-policy_en 13 cfr. Mobility Partnership, availble at https://ec.europa.eu/home-affairs/what-we-do/networks/european_migration_network/glossary_search/mobility-partnership_en 14 EUROMED RIGHT, THE TUNISIA - EU PRIVILEGED PARTNERSHIP, https://euromedrights.org/publication/the-tunisia-eu-privileged-partnership/ $15 \mathrm{cfr}$. The relations between Tunisia and the European Union, available at http://www.aleca.tn/en/decouvrir-l-aleca/relation-tunisie-ue/ 16 FIDES, Politiques du non-accueil en Tunisie, available at http://ftdes.net/rapports/ftdes.migreu.pdf
} 
Asylum. Moreover, the E.U. and Morocco hold a Mobility Partnership Agreement launched in 2019 , investing a total of $€ 343$ million in the partnership ${ }^{17}$.

\section{Categories of Modern coloniality: the concept of the transit country}

Morocco, Algeria and Tunisia have traditionally been considered, and continue to be considered, countries of emigration, to the point that, as we have seen, many bilateral agreements also concern the readmission of nationals ${ }^{18}$. Although they are also countries of immigration, especially Algeria and Morocco, which are characterised by cross-border economic migration both infra-Maghrebian and from sub-Saharan Africa - at times managed through bilateral agreements, such as those between Algeria and Mali - and by specific flows of students or political refugees (as in the case of the Senegalese in Morocco, the African Francophone élites in Tunisia, or the Palestinians in Algeria) ${ }^{19}$. The issue of (possible) transit migration to Europe has raised specifically in two moments: the beginning of political instability and the conflict in the Ivory Coast (2002) and the consequent arrival of part of the 2 million foreign workers who resided in the country, and the deteriorating situation in Libya after 2011 and 2014. Independent of the migratory history of the single countries, their increasing relevance as transit countries has had economic and socio-normative consequences concerning E.U. borders' externalisation strategy.

The first discursive challenge is the meaning of 'transit country', which from the perspective of the E.U. externalisation politics, generally identifies a country as relevant in terms of migration control. Indeed, the concept of transit refers to only one kind of migration, namely the irregular migration of sub-Saharan people whose final destination will be Europe. As Franck Düvell (2006: 6) writes, in the last thirty years, "'transit migration' has become a code for 'illegal immigration, as well as for ineligible asylum seekers". Acquired in the agenda of European migration policies since the 1990s, 'transit migration' negatively connotes specific groups of people and is used to justify restrictive mobility policies and economic support countries considered to be 'transit' ones. Somehow, what European and international organisations seem to suggest is that people arriving in Tunisia, Algeria, and Morocco only have the goal of reaching Europe. This approach, which links economic aid to the refoulement of sub-Saharans, reifies a difference in North Africa's countries. It defines the "unwanted" migrant, and not only for the E.U., but even when referred to national contexts in which regional dynamics would involve different management. In the specific case of the Maghreb- except Tunisia after 2014 -this approach, indeed, denies the fact that most of the migrants' transiting' are transMaghrebian, giving disproportionate attention to the sub-Saharan Mediterranean routes and denying, as well, the Africanity of the Maghreb.

\footnotetext{
$17 \mathrm{cfr}$. COMMUNICATION FROM THE COMMISSION TO THE EUROPEAN PARLIAMENT, THE COUNCIL, THE EUROPEAN ECONOMIC AND SOCIAL COMMITTEE AND THE COMMITTEE OF THE REGIONS The Global Approach to Migration and Mobility /* COM/2011/0743 final */, available at https://eurlex.europa.eu/legal-content/EN/TXT/HTML/?uri=CELEX:52011DC0743\&from=IT

18 cfr. DIRECTORATE GENERAL FOR INTERNAL POLICIES POLICY DEPARTMENT C: CITIZENS' RIGHTS AND CONSTITUTIONAL AFFAIRS CIVIL LIBERTIES, JUSTICE AND HOME AFFAIRS Readmission Policy in the European Union, available at

https://www.europarl.europa.eu/RegData/etudes/etudes/join/2010/425632/IPOL-LIBE_ET(2010)425632_EN.pdf; Jean-Pierre Cassarino. Readmission Policy in the European Union. 2010, 978-92-823-6068-2. ff10.2861/7137ff. ffhal-01232633

19 For a deeper analysis on sub-saharian migration to Algeria see Farrah R. (2020), ALGERIA'S MIGRATION DILEMMA Migration and human smuggling in southern Algeria, Global Initiative against Transnational Organized Crime, available at https://globalinitiative.net/wp-content/uploads/2020/12/Algerias-migration-dilemma-

Migration-and-human-smuggling-in-southern-Algeria.pdf; for Morocco cfr. MPI - Migration Policy Institute,, Morocco: From Emigration Country to Africa's Migration Passage to Europe, available at https://www.migrationpolicy.org/article/morocco-emigration-country-africas-migration-passage-europe/ for Tunisia cfr.IOM, Tunisia,, available at

https://www.iom.int/countries/tunisia\#: :text=Tunisia\%20has\%20also\%20rapidly\%20become\%20an\%20immigration\%20and,Europe \%20through\%20irregular\%20migration $\% 20$ from $\% 20$ the $\% 20$ Tunisian $\% 20$ coasts.
} 
Migration laws in Algeria, Morocco and Tunisia contradict many bilateral agreements, providing for a series of nationality exceptions concerning migrants residing on the territory. The condition of foreigners in Tunisia, for example, is defined by the law 198/ 1968, a law enacted above all for incoming students and that, however, provides for the expulsion of irregular migrants ${ }^{20}$. This law is completed by the 1975 laws on visa and passports, modified by the law number 2004-6 of 3 February 2004 that provides for the payment of a penalty per month for irregular stays. The Decree applies to all persons entering the national territory irregularly or remaining beyond the allowed period. Nevertheless, Tunisia recognises 39 visafree nationalities, including Italy and many African countries: Ivory Coast, Mali, Gambia, Morocco, Algeria, Burkina Faso, Mauritania ${ }^{21}$. For Libyans, the permissible period of stay is extended to 6 months based on a convention signed in 1973 .

E.U. migration policies have influenced the management of migration flow in Morocco: according to Lahlou (2015), the national policy in this concern has had a progressive evolution since the beginning of the '90s. Since then and till 2002/2003, Morocco experienced a period of "non-migration-policy" during which the government showed a relative indifference to the presence of regular residing and transit migrants on its territory. Nevertheless, the progressive changes in E.U. migration policy led Morocco to adopt its first law on migration at the end of 2003, aiming to reduce irregular migration from the country and to reinforce the fight against human trafficking between northwest Africa and Spain. After the Arab protests of 2010-2011, because of the increasing number of immigrants, the enforcement of the mobility agreement with the E.U. and its members, and the need to change the image of the country concerning conditions for receiving irregular migrants pushed the authorities to announce a new migration policy in September 2013, proceeding through a process of migrants' regularisation and the adoption of a series of migration laws (Lahlou, 2015).

In Algeria, the picture is particularly blurred, as, at least in theory, international conventions have relative supremacy over Algerian legislation, according to the 1989 Constitution $^{22}$. In 2008, the framework on the conditions of entry and residence, stuck since 1966, was revised to be aligned with international conventions and, in particular, with the 1990 International Convention on the Protection of the Rights of All Migrant Workers and Members of Their Families ${ }^{23}$, and the 2003 United Nations Convention against Transnational Organized Crime and the related protocols on migrants smuggling and human trafficking ${ }^{24}$. The law 0811/ 2008 applies to all migrants, excepting those coming from a country with whom bilateral agreements exist (this is the case of Mali) and is particularly harsh on the penalisation of irregular migration. It places foreigners in transit - defined as non-resident foreigners transiting through or staying in Algeria for a period not exceeding 90 days, without aiming at establishing residence there or at exercising any professional activity - on the same level as those facilitating the transit. It imposes a monetary penalty and has provisions for the imprisonment of 2 months up to 10 years.

\footnotetext{
20 cfr. Tunisie: Décret No. 1968-198 du 1968, réglementant les conditions d'entrée et de séjour des étrangers en Tunisie, Available at https://www.refworld.org/docid/3ae6b51c14.html

21 Tunisia: migranti, richiedenti asilo e rifugiati, come funziona l'accoglienza, available at https://www.meltingpot.org/Tunisia-migranti-richiedenti-asilo-e-rifugiaticome.html\#.YDwIX2hKjIU; see also Le droit des migrants et des réfugiés dans le cadre du Partenariat Privilégié UE-Tunisie 2013-2017 REMDH 12 avril 2013, available at http://ftdes.net/rapports/Droits_Migrants.pdf

$22 \mathrm{cfr}$. Republique algerienne démocratique et populaire Constitution de 1989, available at http://www.conseil-constitutionnel.dz/index.php/fr/1989 23 cfr. Office of the United Nations High Commissioner for Human Right, The International Convention on Migrant Workers and its Committee, New York and Geneva, 2005, Available at https://www.ohchr.org/Documents/Publications/FactSheet24rev.1en.pdf

24 cfr. United Nations Convention against Transnational Organized Crime and the Protocols Thereto, 29 September 2003, Available at

https://www.unodc.org/unodc/en/organized-crime/intro/UNTOC.html
} 
Moreover, the law creates detention centres for migrants awaiting expulsion for 30 days (which can be renewed), and marriages for a residence permit are penalised. In this law, the penalty against the Harraga, illegal migrants from Algeria, is also harshened and involves provisions against migrants' trafficking and smuggling, adapting Algerian legislation to international protocols ${ }^{25}$. After the Libyan crisis of 2011 and the Malian civil war in 2012, the control of Algerian borders has seen migration issues overlapping with the fear of jihadism, becoming more security-oriented, despite existing readmission agreements (Musette and Khaled, 2014). The international, regional and national attention to borders has sustained in the three countries, albeit with different declinations depending on the political cultures, increasing criminalisation of sub-Saharan migrants, deepening racial tensions and a fostering of discriminatory and oppressive practices towards migrants, which also justify, at an institutional level, forms of deportation which in turn result in the violation of the national sovereignty of sub-Saharan countries (Menin, 2018; Zardo and Loschi, 2020).

\section{Categories of Modern coloniality: the concept of safe country}

The precariousness of migrants' life in the Maghreb contributes to the deconstruction of the idea, standardised by the European Union, of this as an area of safe countries, a pivotal element of the narrative supporting the borders externalisation. It is gained impetus, especially after 2011, when a humanitarian justification began to accompany such policies so that they were considered acceptable by a North African civil society that had shown particular attention to the cause of freedom (Menin, 2018; Zardo and Loschi, 2020). Nevertheless, how to define a country as 'safe'?

The 1979 International Convention on Maritime Search and Rescue (SAR) ${ }^{26}$ (Convention of Hamburg) imposes a specific obligation to rescue and assist people at sea "regardless of the nationality or status of such a person or the circumstances in which that person is found" (art. 2.1.10), also defining as rescue "An operation to retrieve persons in distress, provide for their initial medical or other needs, and deliver them to a place of safety". Thus, the Convention, taking up the directives of the IMO (International Maritime Organization) on the treatment of people rescued at sea, includes the definition of place of safety, above all, the guarantee of protection for the survivors' lives ${ }^{27}$. Following the E.U. 2013/32 directive on common procedures for granting and withdrawing international protection (RECAST) ${ }^{28}$, a country is

\footnotetext{
${ }^{25} \mathrm{cfr}$. JOURNAL OFFICIEL DE LA REPUBLIQUE ALGERIENNE DEMOCRATIQUE ET POPULAIRE, CONVENTIONS ET ACCORDS INTERNATIONAUX - LOIS ET DECRETS ARRETES, DECISIONS, AVIS, COMMUNICATIONS ET ANNONCES, 19 Moharram 142927 janvier 2008, available at https://www.joradp.dz/FTP/jo-francais/2008/F2008004.pdf

${ }^{26} \mathrm{cfr}$. SAR Convention, 1979 INTERNATIONAL CONVENTION ON MARITIME SEARCH AND RESCUE, 1979 as amended by resolution MSC. 70(69), available at https://onboard-aquarius.org/uploads/2018/08/SARConvention-1979.pdf

${ }^{27}$ Art. 3.1.9 of the Convention of 1979, as amended in in 2004 "Parties shall co-ordinate and co-operate to ensure that masters of ships providing-assistance by embarking persons in distress at sea are released from their obligations with minimum further deviation from the ships' intended voyage, provided that releasing the master of the ship from these obligations does not further endanger the safety of life at sea. The Party responsible for the search and rescue region in which such assistance is rendered shall exercise primary responsibility for ensuring such co-ordination and cooperation occurs, so that survivors assisted are disembarked from the assisting ship and delivered to a place of safety, taking into account the particular circumstances of the case and guidelines developed by the Organization. In these cases, the relevant Parties shall arrange for such disembarkation to be effected as soon as reasonably practicable."

${ }^{28}$ cfr. Official Journal of the European Union, DIRECTIVE 2013/32/EU OF THE EUROPEAN PARLIAMENT AND OF THE COUNCIL of 26 June 2013 on common procedures for granting and withdrawing international protection (recast), available at https://eur-lex.europa.eu/legal-content/EN/TXT/PDF/?uri=CELEX:32013L0032
} 
considered safe if, based on the rescued legal status, of the national application of the law within a democratic system and the general political situation, it can be shown that there is no persecution as defined in Article 9 of E.U. Directive 2011/95 ${ }^{29}$, nor danger due to indiscriminate violence in situations because of an internal or international armed conflict. In a safe third country, migrants must not fear either for their life or of torture or other forms of inhuman or degrading treatment or punishment based on race, religion, nationality or belonging to particular social groups or political views. In the safe country, the principle of non-refoulment also has to be respected for those seeking asylum, and if asylum is granted, or if they are eligible for international protection, they have to have the right to legal residence and adequate access to the job market, health and education services recognised.

The definition of a safe third country becomes particularly tricky when the issue of the externalisation of asylum is involved, an issue included as a specific thematic priority of the GAMM (Global Approach to Migration and Mobility), recalled in the E.U. Commission communication "The global approach to migration and mobility" (18 November 2011) ${ }^{30}$. According to the communication, asylum is highlighted as a priority, together with the need to encourage an adequately managed mobility of third-country nationals across the E.U.'s external borders. Therefore, asylum is recognised as part of the forms of mobility control, within partnership agreements, in countries that, despite being part of the international refugee protection system, in signing the Geneva Convention, do not have an organic legal framework concerning procedures for granting protection ${ }^{31}$.

In Tunisia, for example, art. 26 of the Constitution of 2014 recognises that "The right of political asylum is granted according to the law; it is forbidden to extradite people recognised as political asylum beneficiaries" ${ }^{22}$. Lacking specific legislation and applying signed international conventions, the UNHCR is charged with managing the issue and the IOM (which manages assisted returns) and some NGOs. The E.U. has been committed, including financially, to supporting a draft of the law in 2014, revised until 2018, which provides for creating a national refugee protection body to determine the status of the refugee and plans to facilitate access to education, health and work. This was suspended after the death of President Essebsi in 2019.

The question of the lack of national law, even in the face of the constitutionalisation of the right of asylum, also concerns Morocco and Algeria, with an important specific declination, particularly interesting in terms of the racialisation of borders, as the countries have developed a peculiar political use of the refugee status. On the one hand, the two countries shared the difficult management of the Sahrawi issue, representing the majority of foreigners who passed from Morocco to Algeria. On the other hand, Algeria recognises Palestinians as refugees, although not fully benefiting from U.N. protection. In the specific case of Morocco, as previously underlined, the constitutional revision following the Arab Spring, and the formal

\footnotetext{
${ }^{29} \mathrm{cfr}$. Official Journal of the European Union, DIRECTIVE 2011/95/EU OF THE EUROPEAN PARLIAMENT AND OF THE COUNCIL of 13 December 2011 on standards for the qualification of third-country nationals or stateless persons as beneficiaries of international protection, for a uniform status for refugees or for persons eligible for subsidiary protection, and for the content of the protection granted https://eurlex.europa.eu/LexUriServ/LexUriServ.do?uri=OJ:L:2011:337:0009:0026:EN:PDF ${ }^{30} \mathrm{cfr}$. COMMUNICATION FROM THE COMMISSION TO THE EUROPEAN PARLIAMENT, THE COUNCIL, THE EUROPEAN ECONOMIC AND SOCIAL COMMITTEE AND THE COMMITTEE OF THE REGIONS The Global Approach to Migration and Mobility, Brussels, 18.11.2011 COM (2011), available at https://eur-lex.europa.eu/LexUriServ/LexUriServ.do?uri=COM:2011:0743:FIN:EN:PDF

${ }^{31} \mathrm{cfr}$. EU EMERGENCY TRUST FUND FOR AFRICA, available at

https://ec.europa.eu/trustfundforafrica/thematic/improved-migration-management

${ }^{32} \mathrm{cfr}$. Tunisia's Constitution of 2014 , available at

https://www.constituteproject.org/constitution/Tunisia_2014.pdf
} 
recognition of the right to asylum, have led the country to adopt in December 2014 a draft law relating to the national strategy of immigration and asylum following four main aims: the management of migratory flows in compliance with human rights, the implementation of a proper institutional framework, the facilitation of 'regular migrants' integration and the creation of a specific regulatory framework. The latter also includes the opening of an office for refugees and stateless persons in Rabat, with the task of evaluating the applications of refugees already recognised as such by the UNHCR in Morocco and providing support to asylum seekers with their applications. Also, an inter-ministerial National Commission was created to monitor the evaluation of asylum applications. However, according to observers, these structures have not yet accomplished their tasks, especially in increasing the efficiency of applications' management. At the same time, these devices do not consider the violence and racist acts affecting refugees from sub-Saharan Africa (Elmorchid and Hourmat-Allah, 2018). Such violence and forms of racism are not only social but also institutional: a further critical aspect concerns, in fact, the expulsions from Morocco and Tunisia of irregular migrants, their arbitrary detention, inhuman treatment, and denial of appeal procedures during the execution of the expulsion (GADEM 2018a) and other violations of people's fundamental rights, which should be implemented using E.U. funds (GADEM 2018b).

In the face of the lack of specific laws and clear devices for managing asylum applications, the racialisation of the border also follows ideological logics rather than practical ones, sometimes leading to real political aporias.

This is the case, for example, of 2017, when thirteen Syrian refugee families were stranded in the village of Figuig on the Moroccan side of the border with Algeria for three weeks in deplorable conditions, ending up with the death of a child. The two countries handled the situation, opposing each other, although the Syrians are considered refugees by the UNHCR. The Syrians were admitted to Morocco after three months, also due to the pressure of civil society, particularly sensitive to Arab causes ${ }^{33}$. Simultaneously, in Algeria, 40,000 Syrian refugees have been admitted, recognising their access to education and health services, but not to the job market ${ }^{34}$.

\section{Conclusions}

In the E.U.'s policy of borders externalisation, the approach adopted is to define a transversal action of cooperation with countries defined as transit safe countries in terms of harmonisation of legislation, border management, visa policy, readmission agreements and asylum policy. The "global" approach of migration management is based on two pillars: on the one hand, the control of irregular migration and the strengthening of the external dimension of the asylum policy; on the other hand, the link between migration and development both in the contexts of arrival and origin. In this context, this essay, focusing on Tunisia, Morocco and Algeria, has tried to trace the evolution of the external dimension of the E.U. immigration policy, highlighting the instruments and agreements supporting it and reflecting on to what extent this affects these countries, especially concerning their achievement of shared strategic objectives. Beyond the rhetoric of the global approach to the phenomenon of externalisation of borders adopted by the E.U., it has been seen that the main actions are conceived within bilateral agreements between

\footnotetext{
${ }^{33}$ La Repubblica (2017), Marocco, 25 rifugiati siriani intrappolati in un'area desertica al confine con l'Algeria, available at https://www.repubblica.it/solidarieta/profughi/2017/06/08/news/marocco-167583069/

${ }^{34}$ UNHCR (2017), L’UNHCR richiede ulteriori 40.000 posti di reinsediamento per i paesi lungo la rotta del Mediterraneo Centrale, available at https://www.unhcr.org/it/notizie-storie/comunicati-stampa/lunhcr-richiedeulteriori-40-000-posti-reinsediamento-paesi-lungo-la-rotta-del-mediterraneo-centrale/
} 
single European states and partner countries and that the border control is often implemented as an explicit violation of human rights, documented by various governmental and nongovernmental reports.

The practices related to the control of migratory mobility show the inconsistencies of the definition of a third country as safe due to the weak asylum system of the partner countries. However, border control through arbitrary rejections and assisted returns are nothing more than the practical implication of economic aid and cooperation oriented towards managing flows, rather than a response to the rhetoric of development in border areas, one of the pillars of the Commission's Cross Border Cooperation (CBC) document.

The analysis of the blurring of categories of a safe third country to that of transit country has allowed us to go beyond the traditional approach, which sees Maghreb countries as executors of externalisation policies, underlining forms of resistance to bilateral agreements within a specific political geography, escaping the E.U. governance of borders' externalisation. An example is the diversity of approaches of the partner countries concerning sub-Saharan migration, at times welcomed in North African countries, while labelled, as an 'unwanted' economic migration by the E.U. countries; but also forced migration from Syria, that Frenchspeaking partners should, according to the E.U., fully receive, is hindered by Maghreb countries slowing down the policy of externalisation of asylum as conceived in programmatic documents. North African countries' immigration laws concerning cross-border economic migration from the Maghreb and sub-Saharan Africa are fragmented, reflecting teach country's history. This paper has also reported examples of "non-cooperation", as in the E.U. proposal concerning disembarkation platforms for migrants rescued in international waters and different attitudes and resistance to E.U. requests, as in the case of Algeria. The processes described can be considered as reproducing colonial epistemologies, configuring on and around borders, forms of modern coloniality, which would require further theoretical and empirical investigations. Under the Critical Border Theory' approach, indeed, the practical management of Maghreb countries' borders, at the crossroad of E.U. requests and national priorities, shows an A strongly discursive character, especially in terms of borders' racialisation, that determines forms of acceptance or rejection toward migrants and refugees, responding to ideological approaches, rather than institutional arrangements, and reflecting both local and supranational narratives.

\section{References}

Afailal, H. and Fernandez M. (2018), "The Externalization of European Borders: The Other Face of Coloniality Turkey as a Case Study Athens", Journal of Mediterranean Studies, Vol. 4, Issue 3, Pages 215-224

Andersson, R. (2014), Illegality, Inc. Clandestine Migration and the Business of Bordering Europe, Berkeley, CA: University of California Press. Selections.

Bisiaux S.-A. (2020), « La Tunisie, terre d'accueil... des politiques européennes », Plein Droit, 2, 125. Casas-Cortes, M., Cobarrubias S., and J. Pickles (2010), "Stretching Borders Beyond SovereignTerritories? Mapping EU and Spain's Border Externalization Policies.”, Geopolitica 2 (1):

$71-90$.

Düvell F. (2006), "Crossing the Fringes of Europe: Transit Migration in the E.U.'s Neighborhood", Working Paper 06-33, Oxford, Centre on Migration, Policy and Society. 


\section{WORLD COMPLEXITY SCIENCE ACADEMY JOURNAL| Vol. 2 Issue 1, | Spring 2021}

Elmorchid, B. and H. Hourmat-Allah (2018), «Le Maroc face au défi des réfugiés économiques : quelle approche pour quelle gouvernance migratoire ? », Revue européenne des migrations internationales, 34/2 -3, pp. 229-252.

Farrah R. (2020), ALGERIA'S MIGRATION DILEMMA Migration and human smuggling in southern Algeria, Global Initiative against Transnational Organized Crime, available at https:/globalinitiative.net/wp-content/uploads/2020/12/Algerias-migration-dilemma-Migration-andhuman-smuggling-in-southern-Algeria.pdf;

GADEM (2018a), Expulsions gratuites - Note d'analyse sur les mesures d'éloignement mises en oeuvre hors tout cadre légal entre septembre et octobre 2018, Note d'analyse, octobre 2018, available at https://mailchi.mp/808145bec $8 \mathrm{c} 4 /$ note-expulsions-gratuites.

GADEM (2018b), Coûts et blessures - Rapport sur les opérations des forces de l'ordre menées dans le norddu Maroc entre juillet et septembre 2018, Rapport, septembre 2018, available at https://loujnatounkaranke.org/maroc-gadem-couts-et-blessures/

Gammeltoft-Hansen, T. and Sørensen N.N. (2013) (Ed.), The Migration Industry and the Commercialisation of International Migration, New York, Routledge.

Grosfoguel, R. (2007), "The epistemic colonial turn", Cultural Studies,_Vol. 21 (2), pp. 211-223

Gross Wyrtzen L. (2019), Bordering Blackness: The Production of Race in the Morocco-EU Immigration Regime, dissertation, Clark University, Worcester, Massachusetts.

Lahlou M. (2015), Morocco's Experience of Migration as a Sending, Transit and Receiving Country, IAI, working papaers, 15-30 september.

Menin, L. (2018), Being black in North Africa and the Middle Esat, Open democracy 12/02/2018

Mezzadra S. and B. Neilson (2013), Border as Method, or, the Multiplication of Labor, Durham, NC: Duke University Press.

Mignolo, W. (2011), The Darker Side of Western Modernity: Global Futures, Decolonial Options (Latin America Otherwise), Duke University Press Books.

Mountz, A. (2011), "The Enforcement Archipelago: Detention, Haunting, and Asylum on Islands", Political Geography 30 (3): 118-28.

Musette M. S. and Khaled N. (2014), «L'Algérie, pays d'immigration? », Hommes \& migrations, 1298.

Parker N. and Vaughan-Williams N. (2016) (Ed.), Critical Border Studies Broadening and Deepening the 'Lines in the Sand' Agenda, London, Routledge.

Quijano A. (2007), 'Coloniality and Modernity/Rationality', Cultural Studies, 21: 2, pp. 168-178.

Zardo F. \& Loschi C. (2020), EU-Algeria (non) cooperation on migration: A tale of two fortresses, Mediterranean Politics.

This article is distributed under the terms of the Creative Commons Attribution 4.0 License (https://creativecommons.org/licenses/by/4.0/) which permits any use, reproduction and distribution of the work without further permission provided the original work is attributed as specified on the WCSA Journal by World Complexity Science Academy (https://www.wcsaglobal.org/ethics-policy/). 